Article

\title{
Origin of Mesozoic Porphyritic Rocks and Regional Magmatic Evolution in the Zijinshan Ore Field of Fujian Province, China: Hf-O Isotope Characteristics of Magmatic Zircons
}

\author{
Wenhui Zhang ${ }^{1, *}$, Liyuan Wang ${ }^{1, *}$, Xupeng $\mathrm{Lv}^{2}$, Xiaomin $\mathrm{Li}^{1}$, Shuaiqi Yan ${ }^{1}$ and Juntao Nie ${ }^{1}$ \\ 1 College of Zijin Mining, Fuzhou University, Fuzhou 350108, China; lixm601@163.com (X.L.); \\ 15284060615@163.com (S.Y.); NJT756375940@163.com (J.N.) \\ 2 Yunnan Institute of Geological Survey, Kunming 650000, China; lxpwty001@163.com \\ * Correspondence: whzhang@fzu.edu.cn (W.Z.); wangliyuan030101@163.com (L.W.)
}

Received: 15 November 2020; Accepted: 17 December 2020; Published: 20 December 2020

\begin{abstract}
Mesozoic porphyritic rocks from the Zijinshan area, southwestern Fujian Province, China, are andesitic to rhyolitic in composition. The whole-rock $\mathrm{SiO}_{2}$ contents of these rocks are between $62.5 \%$ and $78.1 \%$. Magmatic zircon from the Mesozoic porphyritic rocks was determined via secondary-ionization mass spectrometry (SIMS) for the $\mathrm{U}-\mathrm{Pb}$ age and $\mathrm{Hf}$ and $\mathrm{O}$ isotopes. The zircon U-Pb ages could be mainly divided into three age groups: Group 1: 138.8 Ma; Group 2: 109.2 107.4 Ma; and Group 3: 99.7 98.2 Ma. The $\varepsilon H f(t)$ and $\delta^{18} \mathrm{O}$ values of the porphyritic zircons showed that the porphyritic rocks in Group 2 were more affected by mantle-derived magma. Combined with previous research results, the medium-acidic magmatism in the southwestern Fujian Province can be divided into eight periods: Paleoproterozoic, Mesoproterozoic, Middle Neoproterozoic, Silurian to Lower Devonian, Permian to Triassic, Middle Jurassic to early Lower Cretaceous, late Lower Cretaceous, and late Lower Cretaceous to early Upper Cretaceous. The Paleoproterozoic crust was the predominant magmatic source for the subsequent Mesoproterozoic to Jurassic magmatism, but the only melts that were closely related to mineralization were derived from partial melting of the Mesoproterozoic crust and a more depleted upper mantle.
\end{abstract}

Keywords: SIMS zircon U-Pb age; Hf-O isotopes; crust-mantle interaction; Zijinshan ore field

\section{Introduction}

The Zijinshan ore field, the largest porphyry-epithermal mineralization system in southeast China, is located in the southwestern Fujian Province (Figure 1) [1,2]. The major economic deposits in the region include: (1) the Zijinshan high-sulfidation epithermal deposit [3-5], (2) the Luoboling Cu-Mo-Au porphyritic deposit [6], (3) the Yueyang low-sulfidation epithermal Ag polymetallic deposit [7], and (4) the Wuziqilong transitional $\mathrm{Cu}$ deposit [8,9]. Zijinshan mineralization was closely related to two large-scale intermediate-acid magmatic activities in the Mesozoic: late Jurassic (165-149 Ma) and Cretaceous (118-92 Ma) [10-14]. The late Jurassic intrusive rocks were mainly composed of medium-to coarse-grained monzogranite and granite, and the early Cretaceous intrusive-volcanic rocks were mainly hypabyssal intrusive rock or subvolcanic porphyries such as granodioritic porphyry, granitic porphyry, quartz porphyry, and dacitic porphyry. The dacitic and/or granodioritic porphyries were strongly associated with the Zijinshan $\mathrm{Cu}-\mathrm{Au}$ deposit and the Luoboling porphyry $\mathrm{Cu}-\mathrm{Mo}$ mineralization $[15,16]$. 


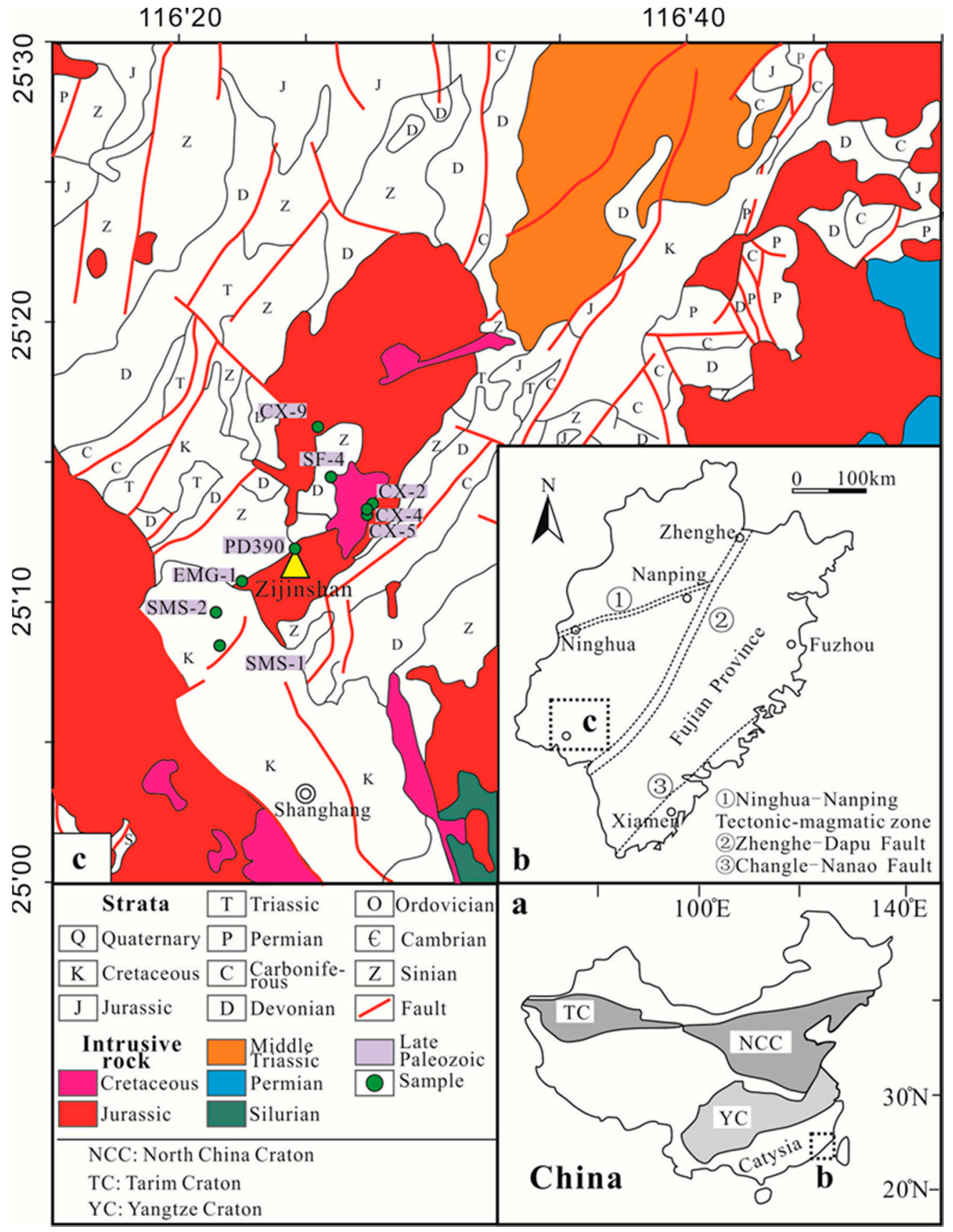

Figure 1. Geological sketch map of the China (a), Fujian Province (b), and the Zijinshan area (c).

As Cretaceous porphyritic rocks play an important role in mineralization, much attention has been paid to their genesis [14,17]. However, as the magmatic rocks in the Zijinshan area were usually subjected to intense alteration, it is difficult to completely describe the characteristics of the original magma from a whole-rock geochemical study. Even though zircon Hf isotopes have been conventionally used to study the origin of these rocks $[4,10]$, the large range of Hf isotopic compositions from various mantle sources sometimes prevents the effective identification of the magmatic source and, thus, the genesis of the economic ore deposits.

In addition to $\mathrm{U}, \mathrm{Pb}$, and $\mathrm{Hf}$ isotopes, zircon has a high closure temperature for oxygen. Oxygen isotopes retain their original basic oxygen isotope characteristics even during high-grade eclogite-facies metamorphism and, therefore, work as more effective indicators for magma genesis [18]. Studies of oxygen isotopes in magmatic zircons have shown that mantle-derived zircons have almost 
uniform $\delta^{18} \mathrm{O}$ values $\left(5.3 \pm 0.6 \%\right.$ ) $[19,20]$. Increasing $\delta^{18} \mathrm{O}$ values generally indicate the involvement of crustal materials in a magmatic source. Therefore, the oxygen isotopic signatures of magmatic zircons can provide robust indicators of the interaction between crust and mantle in a given region [21-24].

In this study, we focus on Mesozoic porphyritic rocks in the Zijinshan area, as these rocks are closely related to the formation of economic ore deposits. The zircon Hf-O isotopic data of the porphyritic rocks demonstrated that the mantle-derived materials contributed more to the early Cretaceous melts than the late Cretaceous ones. The Jurassic porphyritic rocks showed more involvement in crustal materials. We also discuss the magmatic evolution of the crustal source from Proterozoic to Mesozoic.

\section{Geological Background and Petrography}

\subsection{Geological Background}

The Zijinshan area is located in the southwestern Fujian Provence (Figure 1b), China (Figure 1a). The northwest-striking Yunxiao-Shanghang fault zone and several northeast-orienting Xuanhe anticlinoria are the chief ore-controlling structures. Flysch sediments metamorphosed by the Sinian and early Paleozoic periods are outcropped in the Zijinshan area (Figure 1c). The Indosinian orogeny, which occurred in the eastern part of China during the early Triassic, resulted in a change in the tectonic framework in Southeast China from the predominantly Tethys tectonic domain to the circum Pacific active continental margin [25-28]. The orogeny formed a series of intermediate-acid igneous rocks accompanied by large-scale mineralization [25].

The Cretaceous (105 Ma) granodioritic porphyry invaded and was extensively buried at the depth of this area, which was not only associated with the Zhongliao porphyry copper (molybdenum) deposit but also provided a heat source for the epigenetic hydrothermal $\mathrm{Cu}$-Au deposits that resulted in large-scale $\mathrm{Cu}-\mathrm{Au}$ mineralization [29-33]. However, the dacitic porphyry contributed to the Zijinshan $\mathrm{Cu}-\mathrm{Au}$ deposit, while the granodioritic porphyry contributed to the Luoboling Cu-Mo ore [34].

\subsection{Petrography}

Nine samples were collected for studies of bulk-rock chemistry and $\mathrm{U}-\mathrm{Pb}, \mathrm{Hf}$, and $\mathrm{O}$ isotopes of zircon. Microscopic photographs of representative samples are shown in Figure 2. The porphyritic rocks in the region were found to be mainly granitic porphyry, with a minor amount of granodioritic porphyry (sampe CX-5). The granitic porphyry had a porphyritic texture (Figure $2 a, b$ ), with the matrix of a microcrystalline-cryptocrystalline texture (Figure 2d). We found that some materials of the matrix were devitrified (Figure 2c). The content of phenocrysts was found to be about $20-30 \%$, mainly composed of alkali feldspar, plagioclase, quartz, and a small amount of biotite and amphibole. The alkali feldspar was in the shape of a euhedral-subhedral plate, exhibiting common kaolinization and, to a lesser degree, sericitization. The quartz was granular and normally eroded. Some quartz grains underwent late hydrothermal carbonate alteration (Figure 2e). The biotite was generally chloritized with an abnormal interference color (Figure 2d,h). The amphiboles were also strongly altered by carbonation and chloritization (Figure 2f). Sericitization was common in the plagioclase (Figure $2 n$ ). The granodioritic porphyry had a porphyritic structure with some phenocrysts fragmented and cut through by the late quartz veins (Figure $2 \mathrm{k}$ ). The fine-grained matrix consisted of long strips of plagioclase that were arranged roughly in orientation. 


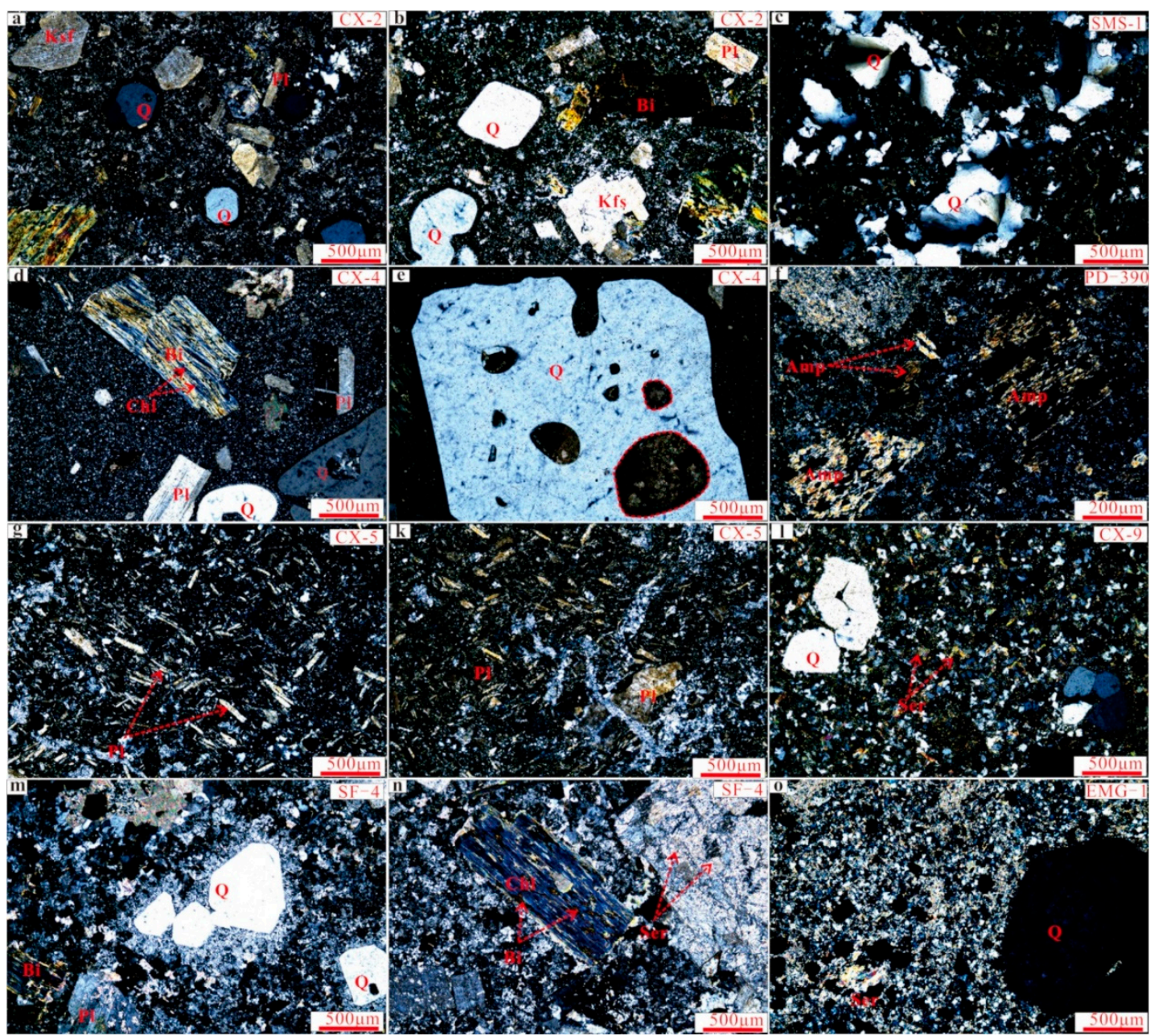

Figure 2. Photographs showing micro-structures of the studied porphyry in the Zijingshan area. $(\mathbf{a}, \mathbf{b})$ granite porphyry with plagioclase and quartz phenocrysts; (c) felsic minerals matrix of the granitic porphyry developed devitrification phenomenon; (d) chloritization was developed along the cleavage fracture of biotite; (e) quartz phenocrysts of granitic porphyry were featured frequently with melting corrosion structure; (f) amphiboles were strongly altered with carbonation and chloritization; ( $\mathbf{g}-\mathbf{k})$ granodioritic porphyry had a porphyritic structure, and plagioclase microcrystals were developed in the matrix; (i) quartz phenocrysts set in a fne- to micro-grained holocrystalline matrix; (m) quartz phenocryst with a typical recrystallized rim with micro-inclusions; $(\mathbf{g}-\mathbf{k})$ the matrix had a microcrystalline structure, and plagioclase was partially sericized; (n) biotite and plagioclase phenocrysts developed chloritization and sericization, respectively; and (o) plagioclase in the matrix had obvious sericization; abbreviations: Q: quartz; Pl: plagioclase; Kfs: K-feldspar; Bi: biotite; Amp: amphibole; Ser: Sericite; and Chl: chlorite.

\section{Analytical Methods}

\subsection{Major and Trace Element Analysis}

Whole-rock samples were analyzed for major and trace elements at the Institute of Regional Geology and Mineral Resources Survey in Hebei Province, China. The major elements were analyzed using the X-ray fluorescence (XRF) method with an analytical error of $<2 \%$. Rare earth and other trace elements were analyzed by using plasma mass spectrometry (ICP-MS) with an analytical error of $<5 \%$. 


\subsection{Zircon $\mathrm{U}-\mathrm{Pb}$ Dating}

Zircons from about $20 \mathrm{~kg}$ of the sample were first separated using magnetic and heavy liquid separation methods, and then it was hand-picked under a binocular microscope. Zircon grains and a standard sample (Qinghu, Plésovice and 91500) were stuck onto the target using epoxy resin, and gold was sprayed on the surface after polishing the internal zircon. The morphology and internal structure of the zircons were studied using the cathodoluminescence (CL) technique with a JXA-8100 Electron Probe Microanalyzer for high-resolution imaging and spectroscopy at the State Key Laboratory of Continental Tectonics and Dynamics in Chinese Academy of Geological Sciences. The zircon in-situ O isotopic ratios were analyzed first, and the $\mathrm{U}-\mathrm{Pb}$ and $\mathrm{Hf}$ isotope were subsequently analyzed at the same point.

Zircon $\mathrm{U}-\mathrm{Pb}$ and $\mathrm{Pb}-\mathrm{Pb}$ dating were conducted using a Cameca IMS 1280 ion microprobe (secondary-ionization mass spectrometry (SIMS)) at the Institute of Geology and Geophysics, Chinese Academy of Sciences (CAS) in Beijing. The detailed method of the analysis can be found in [18]. A single $\mathrm{O}_{2}{ }^{-}$ion beam $(20 \times 30 \mu \mathrm{m}$ in size with $10 \mathrm{nA}$ of strength) bombarded the sample surface with an acceleration voltage of $-13 \mathrm{kV}$. Oxygen flow increased the sample chamber pressure to approximately $5 \times 10^{-6} \mathrm{~T}$ in order to improve the sensitivity of the $\mathrm{Pb}^{+}$ion in zircon. Seven sets of data were analyzed for each sample spot, and the measuring time was approximately $12 \mathrm{~min}$. The obtained standard deviation of $1.5 \%(1 \sigma)$ through long-term monitoring of the standard sample [34] and the internal test accuracy of single sample points together determined the single point error. Standard zircon 91500 $(1065 \mathrm{Ma})$ was used to correct the $\mathrm{Pb} / \mathrm{U}$ ratios and calculate the Th and $\mathrm{U}$ contents of the zircon samples $\left(\mathrm{Th}=29 \mu \mathrm{g} / \mathrm{g} ; \mathrm{U}=81 \mu \mathrm{g} / \mathrm{g}\right.$ ) [35]. Ordinary $\mathrm{Pb}$ was corrected by measuring ${ }^{204} \mathrm{~Pb}$. The analysis error of the isotope ratio and age for a single point was $1 \sigma$. The data were processed using the ISOPLOT software [36].

\subsection{O Isotope Analysis}

Zircon in-situ O isotopes were also analyzed by using the Cameca IMS 1280 ion microprobe (CASIMS) at the Institute of Geology and Geophysics at the CAS. A detailed analysis method can be found in [37]. A single ${ }^{133} \mathrm{Cs}^{+}$ion beam with a strength of $2 \mathrm{nA}$ bombarded the sample surface and then received both ${ }^{16} \mathrm{O}$ and ${ }^{18} \mathrm{O}$ at the same time via two Faraday cups. The single-point measurement time was approximately $5 \mathrm{~min}$, and the accuracy of the single group ${ }^{18} \mathrm{O} /{ }^{16} \mathrm{O}$ data were generally better than $0.2 \%-0.3 \%$ o $(1 \sigma)$. The external precision of the sample was $0.5 \%$ o (2SD). The quality fractionation of the instrument was corrected by the Penglai zircon standard [34]. The measured ${ }^{18} \mathrm{O} /{ }^{16} \mathrm{O}$ ratio was corrected using the Vienna standard mean ocean water (V-SMOW) value $\left({ }^{18} \mathrm{O} /{ }^{16} \mathrm{O}=0.0020052\right)$. In this study, $\left(\delta^{18} \mathrm{O}\right)_{\mathrm{M}}=\left(\left({ }^{18} \mathrm{O} /{ }^{16} \mathrm{O}\right)_{\mathrm{M}} / 0.0020052-1\right) \times 1000(\%$ ) $=\left(\delta^{18} \mathrm{O}\right)_{\mathrm{M}(\text { standard })}-\left(\delta^{18} \mathrm{O}\right)_{\mathrm{VSMOW}}, \delta^{18} \mathrm{O}_{\text {sample }}=\left(\delta^{18} \mathrm{O}\right)_{\mathrm{M}}+\mathrm{IMF}$.

\subsection{Hf Isotope Analysis}

In-situ zircon Lu-Hf isotopic measurements were performed on a Neptune Plus Multi Collector -ICP-MS, coupled with a $193 \mathrm{~nm}$ resolution laser ablation system at the Institute of Geology and Geophysics at the CAS. A detailed description of analytical methods can be found in [38]. The time of laser ablation was $26 \mathrm{~s}$. The laser ablation pulse frequency was $10 \mathrm{~Hz}$, and the pulse power was $100 \mathrm{~mJ}$, with a beam spot size of approximately $60 \mu \mathrm{m}$. The isobaric interference of ${ }^{176} \mathrm{Lu}$ and ${ }^{176} \mathrm{Yb}$ to ${ }^{176} \mathrm{Hf}$ was rectified by monitoring the signal strength of ${ }^{175} \mathrm{Lu}$ and ${ }^{172} \mathrm{Yb}$ using the ${ }^{175} \mathrm{Lu} /{ }^{176} \mathrm{Lu}$ ratio (0.02655) and the ${ }^{176} \mathrm{Yb} /{ }^{172} \mathrm{Yb}$ ratio (0.5886), respectively [39]. Standard zircon 91500 crossing with zircon sample analysis was used for the external monitoring of instrument drift. In the process of the analysis, the average ${ }^{176} \mathrm{Hf} /{ }^{177} \mathrm{Hf}$ ratio for the zircon standard Mud Tank was $0.282491 \pm 27(2 \sigma)$, and it was $0.281971 \pm 26(2 \sigma)$ for GJ, which was consistent with the results of the literature within the error range [40]. The $\mathrm{EHf}$ value and two phase model calculation age were calculated according to [38] and the references therein using $\left({ }^{176} \mathrm{Lu} /{ }^{177} \mathrm{Hf}\right) \mathrm{CHUR}=0.0332 ;\left({ }^{176} \mathrm{Hf} /{ }^{177} \mathrm{Hf}\right) \mathrm{CHUR}, 0=0.28277$; 
$\left({ }^{176} \mathrm{Lu} /{ }^{177} \mathrm{Hf}\right) \mathrm{DM}=0.0384$; and $\left({ }^{176} \mathrm{Hf} /{ }^{177} \mathrm{Hf}\right)_{\mathrm{DM}}=0.28325$. The $\mathrm{f}_{\mathrm{CC}}, \mathrm{f}_{\mathrm{s}}$, and $\mathrm{f}_{\mathrm{DM}}$ represent the $\mathrm{f}_{\mathrm{Lu} / \mathrm{Hf}}$ of the continental crust, samples, and depleted mantle, respectively. $\mathrm{T}$ is the age of sample formation. $\Lambda=1.867 \times 10^{-11}$ year $^{-1}$.

\section{Results}

\subsection{Zircon SIMS U/Pb Age}

The analyzed zircons were mostly colorless and transparent crystals, ranging from semi-automorphic to idiomorphic, with a length of 100-400 $\mu \mathrm{m}$ and varying length/width ratio from 1:1 to 4:1. The CL images clearly showed that the internal structure of the zircons was oscillatory zoning (Figure 3). No influence of alteration on these zircon grains was observed. The Th/U ratios of the zircons were generally $>0.1$ (Supplementary Table S1), which is typical of magmatic zircons [41].

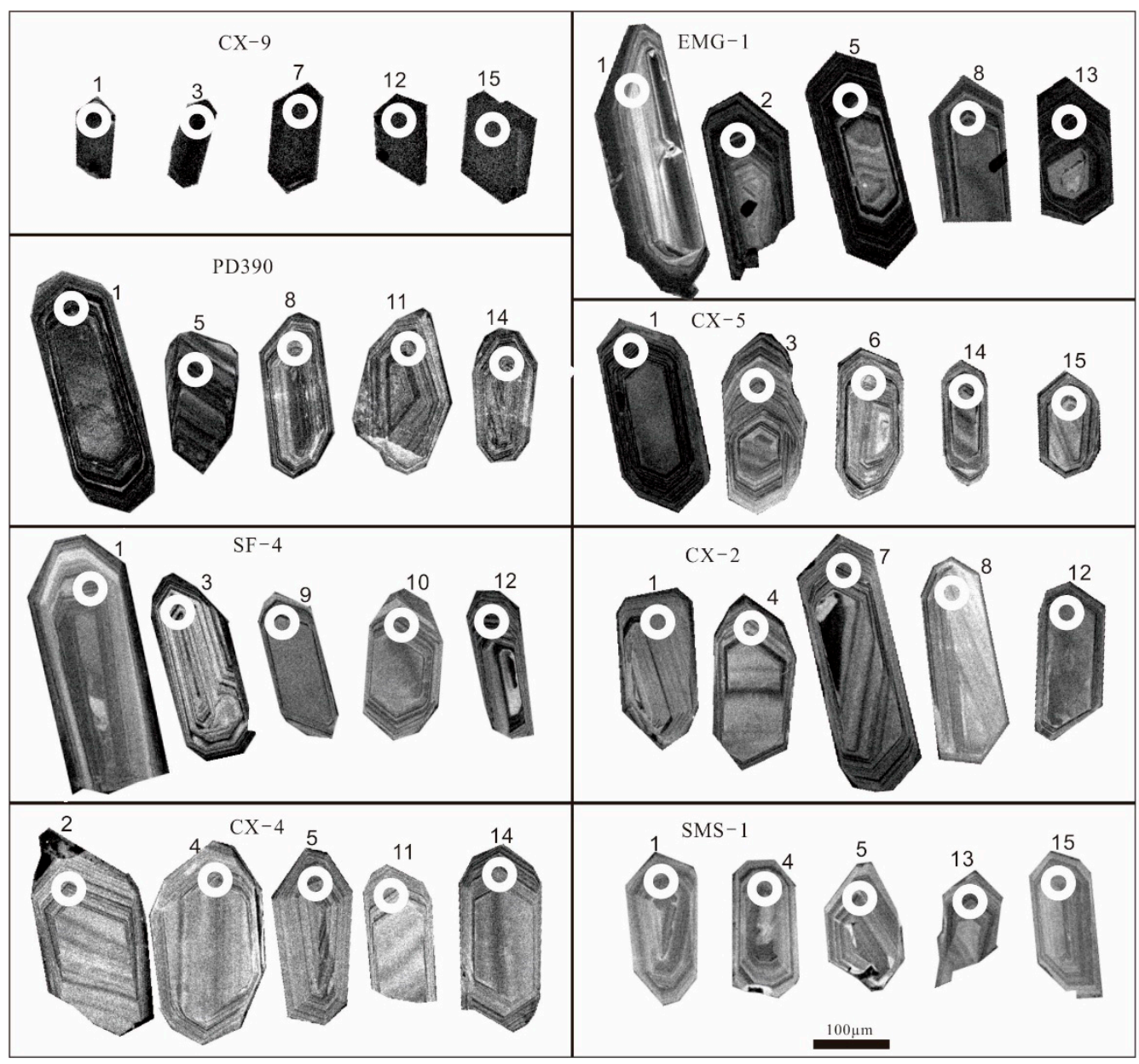

Figure 3. Zircon cathodoluminescence (CL) images of porphyritic rocks from the Zijinshan area. The white circle represents the analysis location of the $\mathrm{Hf}-\mathrm{O}$ and $\mathrm{U} / \mathrm{Pb}$ isotopes.

The detailed dating results are listed in Supplementary Table S1. Because of errors in counting statistics during the analysis, the ${ }^{207} \mathrm{~Pb} /{ }^{206} \mathrm{~Pb}$ ages were more accurate for older (>1 Ga) zircons, whereas the ${ }^{206} \mathrm{~Pb} /{ }^{238} \mathrm{U}$ ages were more accurate for younger zircons [42]. Therefore, we use the ${ }^{206} \mathrm{~Pb} /{ }^{238} \mathrm{U}$ ages for younger zircons in the following discussion.

Fifteen analyses on zircon grains from sample CX-9 yielded concordant ${ }^{206} \mathrm{~Pb} /{ }^{238} \mathrm{U}$ dates ranging from $136.9 \pm 2.0$ to $141.2 \pm 2.1$ Ma with a weighted mean age of 138.8 $\pm 1.1 \mathrm{Ma}(\mathrm{MSWD}=15 ;$ Figure 4 ). Zircon samples from EMG-1, PD-390, and CX-5 displayed a weighted mean age in the range of 
109.2-107.4 Ma. They yielded concordant ${ }^{206} \mathrm{~Pb} /{ }^{238} \mathrm{U}$ dates ranging from $103.7 \pm 1.6$ to $118.2 \pm 1.4 \mathrm{Ma}$, except for one (EMG-1@13) that was 153.0 \pm 2.3 Ma. Zircon samples from SF-4, CX-2, CX-4, SMS-1, and SMS-2 displayed a weighted mean age in the range of 99.7-98.2 Ma, with concordant ${ }^{206} \mathrm{~Pb} /{ }^{238} \mathrm{U}$ dates ranging from $103.9 \pm 1.5$ to $96.5 \pm 1.5 \mathrm{Ma}$. Two xenocrystic zircons had ages of 224.8.0 $\pm 3.3 \mathrm{Ma}$ (SF-4@13) and $755.6 \pm 10.7$ (SMS-2@13).
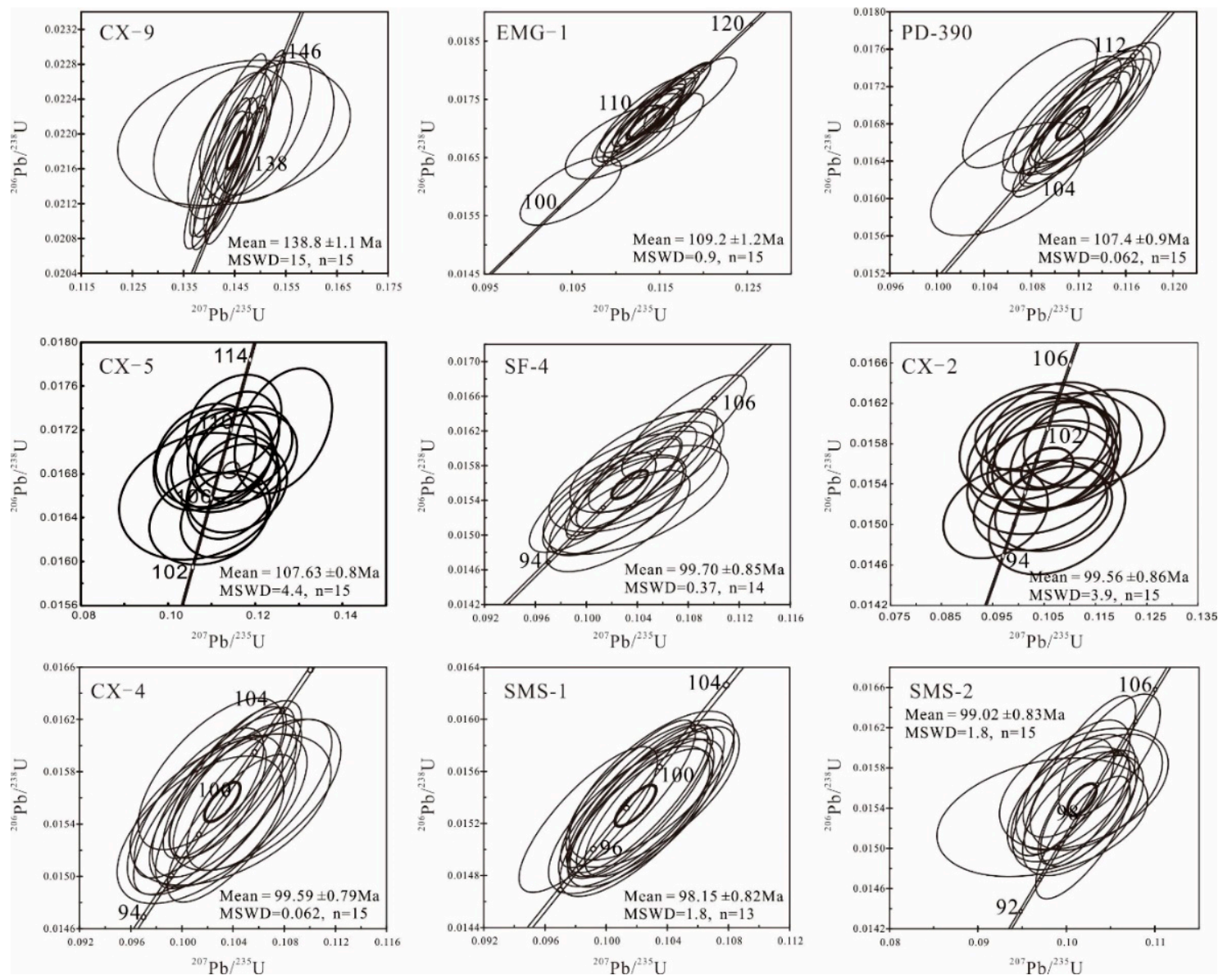

Figure 4. U-Pb Concordia plots illustrating the U-Pb ages of porphyritic rocks from the Zijingshan area.

Excluding ages from the xenocrystic zircons, the ages were divided into three groups: Group 1: 138.8 Ma; Group 2: 109.2-107.4 Ma; and Group 3: 99.7-98.2 Ma.

\subsection{Characteristics of Major and Trace Elements}

The whole-rock $\mathrm{SiO}_{2}$ contents of the sample ranged from 62.46 to $78.09 \%$. The relatively high $\mathrm{SiO}_{2}$ contents are usually combined with low $\mathrm{Fe}_{2} \mathrm{O}_{3}{ }^{\mathrm{T}}, \mathrm{MgO}$, and $\mathrm{CaO}$ (Supplementary Table S2). The porphyry were characterized by low-to-high concentrations of $\mathrm{Na}_{2} \mathrm{O}$ between $0.09 \%$ and $4.27 \%$, high $\mathrm{K}_{2} \mathrm{O}$ and $\mathrm{Na}_{2} \mathrm{O}$ between $4.24 \%$ and $8.98 \%$, $\mathrm{MgO}$ of $0.1-3.6 \%$ with most lower than $1 \%$, and $\mathrm{Al}_{2} \mathrm{O}_{3}$ between 11.63 and $15.92 \%$. In the $\mathrm{SiO}_{2}$ versus $\mathrm{K}_{2} \mathrm{O}$ and $\mathrm{Na}_{2} \mathrm{O}$ diagram, most samples plotted in the granite and granodiorite fields (Figure 5a). They had high $\mathrm{K} 2 \mathrm{O}$ contents (3.27-8.85\%), and all samples were located in the subalkaline and high-K calc-alkaline fields (Figure $5 \mathrm{~b}$ ). The aluminum saturation index values (A/CNK) varied from 0.95 to 3.26, indicating metaluminous-to-strongly peraluminous characteristics. 

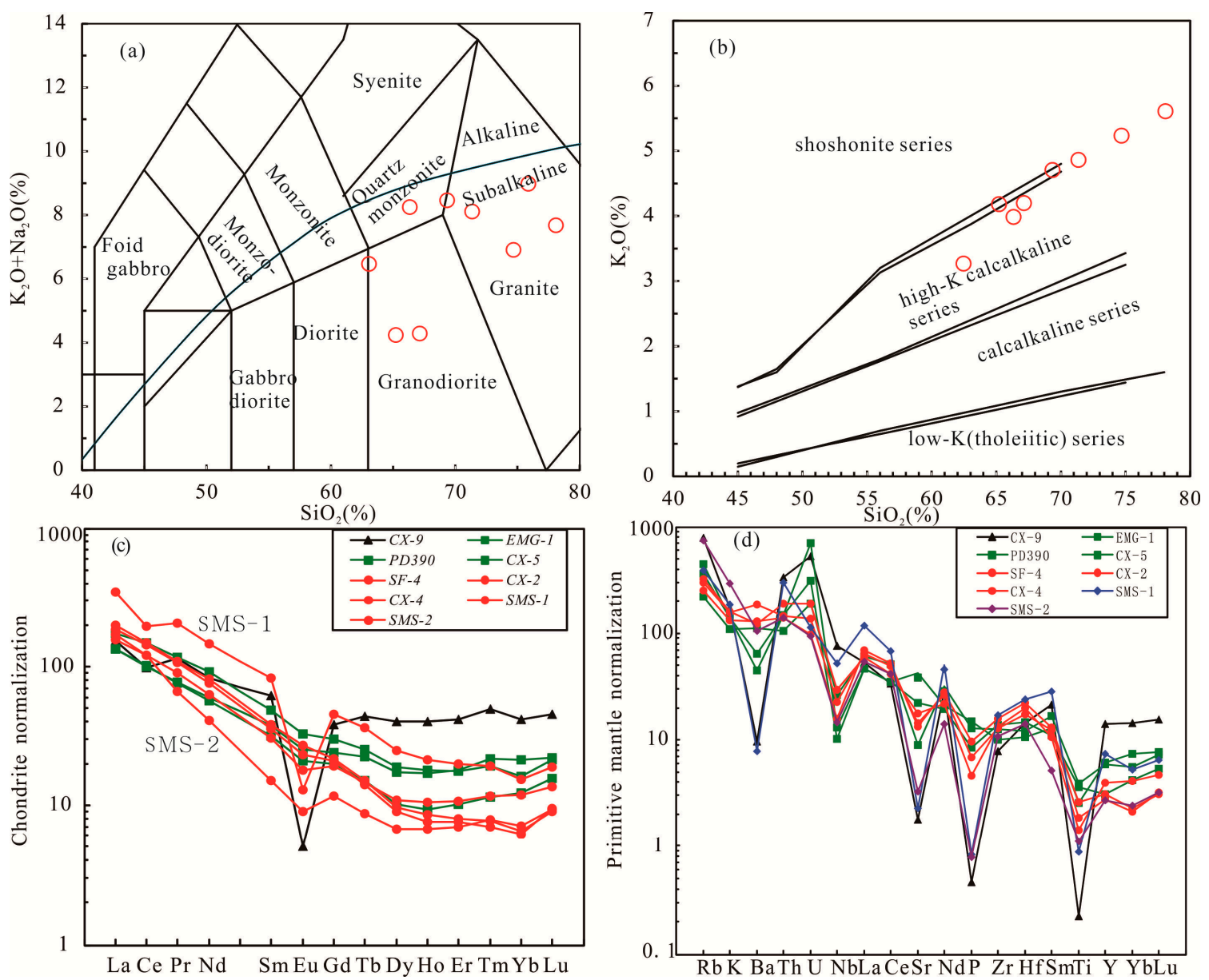

Figure 5. Geochemical classification diagrams of porphyritic rocks from the Zijingshan area. (a) TAS (Total Alkali vs. Silica) diagram; (b) $\mathrm{K}_{2} \mathrm{O}$ versus $\mathrm{SiO}_{2}$ diagram; (c) standardized rare earth element; and (d) incompatible trace element diagrams.

Most samples were enriched in light rare earth elements (LREEs) and moderately depleted in heavy rare earth elements(HREEs), with total amounts of 146.3-215.6 ppm. In the chondrite-normalized rare earth element (REE) patterns (Figure 5c), all samples showed obvious enrichment in LREEs $\left((\mathrm{La} / \mathrm{Yb})_{\mathrm{N}}=6.32-30.71\right)$ with moderately negative Eu anomalies $\left(\mathrm{Eu} / \mathrm{Eu}^{*}=0.21-0.94\right)$. Such REE patterns reflected feldspar fractional crystallization or poorly soluble residuum in the early stage of magmatism. The contents of the HREEs decreased with age, with sample CX-9 (age = 138.8 $\pm 1.1 \mathrm{Ma}$ ) showing the highest contents of $\mathrm{Yb}$ and $\mathrm{Lu}(7.13$ and $1.15 \mathrm{ppm}$, respectively) and the CX-2 (age $=99.56$ $\pm 0.86 \mathrm{Ma}$ ) showing the lowest (1.04 and $0.24 \mathrm{ppm}$, respectively). Strongly negative Eu anomalies could be observed in samples CX-9 and SMS-1, indicating that they may have been formed in low oxygen fugacity and consequently experienced the significant crystallization of plagioclase in the magma source area.

The trace element abundance diagrams of the porphyritic rocks display roughly similar patterns with negative anomalies of $\mathrm{Ba}, \mathrm{Nb}, \mathrm{Sr}, \mathrm{P}$, and $\mathrm{Ti}$ anomalies combined with small positive $\mathrm{Rb}, \mathrm{Th}, \mathrm{U}$, $\mathrm{La}, \mathrm{Ce}, \mathrm{Nd}$, and $\mathrm{Hf}$ anomalies (Figure $5 \mathrm{~d}$ ). The enrichment in LILEs and depletion in HFSEs in the porphyry samples indicate the influence of fluids in subduction conditions. The significant negative $\mathrm{Ba}$ anomalies are thought to be the result of alkali feldspar-dominated fractionation. Positive $\mathrm{Rb}$ and negative $\mathrm{Sr}$ anomalies, both of which are associated with negative Eu anomalies, are consistent with dominant plagioclase fractionation. The significant Ti depletions were due to magnetite and ilmenite fractionation. 
As the alteration of the Mesozoic granite samples in the Zijinshan area is strong, its major and trace elements may not be reliably used to describe the characteristics of the source region.

\subsection{O-Isotope Composition of Zircons}

The zircon oxygen isotopic data are listed in Supplementary Table S3 and shown in Figure 6. The $\delta^{18} \mathrm{O}$ values of the Group 1 ( 138.8 Ma) zircons ranged from 6.96 to $8.17 \%$, and those of Group $2(109.2-107.4 \mathrm{Ma})$ ranged from 5.54 to $7.72 \%$. The $\delta^{18} \mathrm{O}$ values of the Group 3 (99.7-98.2 Ma) zircons ranged from 6.34 to $7.62 \%$, with one showing an extremely high value $\left(\delta^{18} \mathrm{O}=9.02\right.$ of SF-4@11). Additionally, two inherited zircon grains from the EMG-1 and SF-4 (153.0 and 224.8 Ma) showed extremely high $\delta^{18} \mathrm{O}$ values (9.27 and $10.45 \%$, respectively).
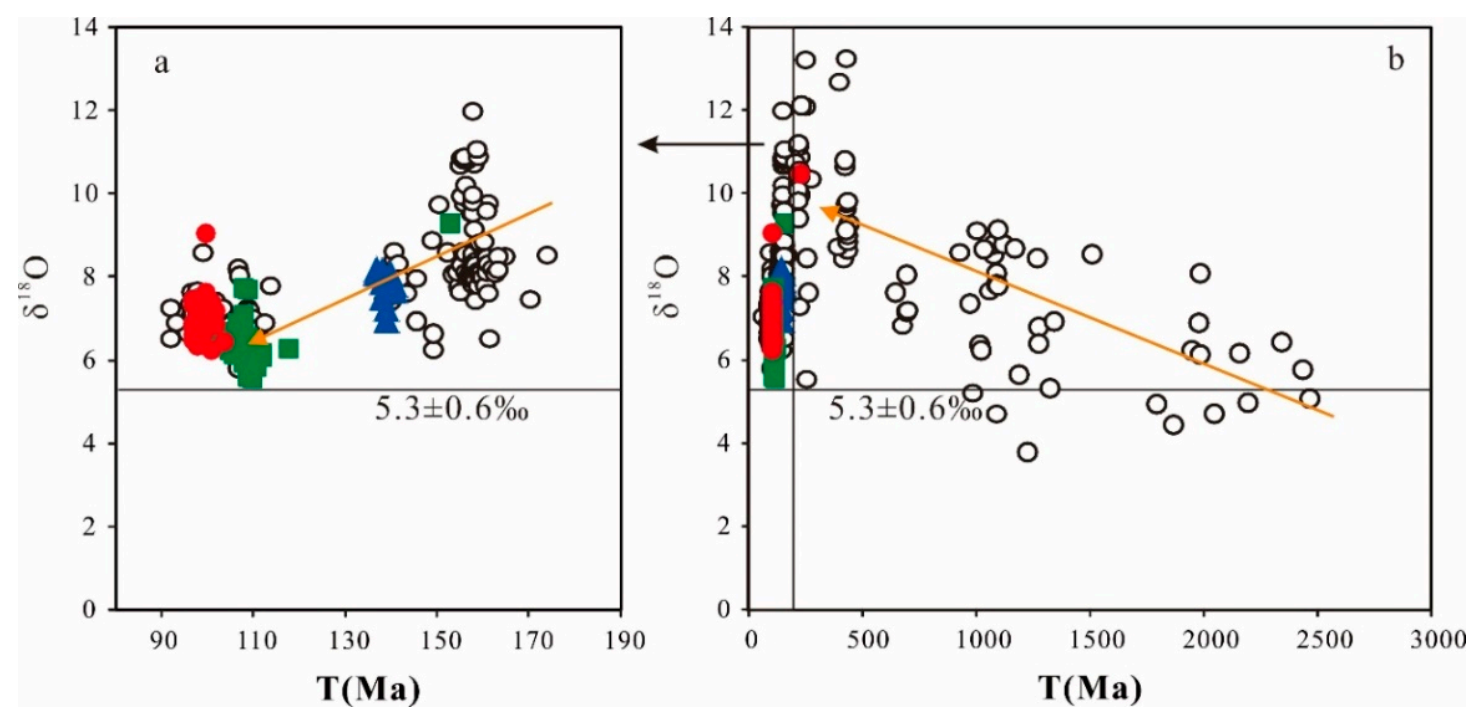

Figure 6. Zircon $\delta^{18} \mathrm{O}$ versus magmatic zircons age from the Zijinshan ore field. $\delta^{18} \mathrm{O}$ value in mantle zircons $=5.3 \pm 0.6$ (2SD) [19]. Blue triangle represents Group 1, green box represents Group 2, red circles represent Group 3, and white circles represent other literature data. (a) oxygen isotopic characteristics of Zircons from the Jurassic to Cretaceous period; (b) oxygen isotopic characteristics of zircons from proterozoic to Cretaceous in the study area, note that Precambrian zircons show a negative correlation (increase in $\delta^{18} \mathrm{O}$ with time).

\subsection{Hf-Isotope Compositions of Zircons}

Lu-Hf isotopic ratios were determined on the same or similar domains as the zircon grains analyzed for $\mathrm{U}-\mathrm{Pb}$ and $\mathrm{O}$ isotopes. The analytical results are listed in Supplementary Table S3 and shown in Figure 7. The $\varepsilon H f(t)$ values were calculated using their $\mathrm{U}-\mathrm{Pb}$ ages. The $\varepsilon \mathrm{Hf}(\mathrm{t})$ values of Group 1 zircons ranged from -6.1 to -15.3 , and those for Group 2 ranged from 1.6 to -5.3 . The $\varepsilon H f$ values of Group 3 zircons ranged from 0.0 to -7.5 , with two grains having extremely low $\varepsilon \mathrm{Hf}(\mathrm{t})$ values. Zircon SF-4@11 had a low $\varepsilon \mathrm{Hf}(\mathrm{t})$ of -12.5 , with a high $\delta^{18} \mathrm{O} \%$ of 9.02 , whereas zircon SMS-1@9 had an even lower $\varepsilon \mathrm{Hf}(\mathrm{t})$ of -20.4 , with a normal $\delta^{18} \mathrm{O}$ value $\left(\delta^{18} \mathrm{O} \%\right.$ o $\left.=6.34\right)$. 

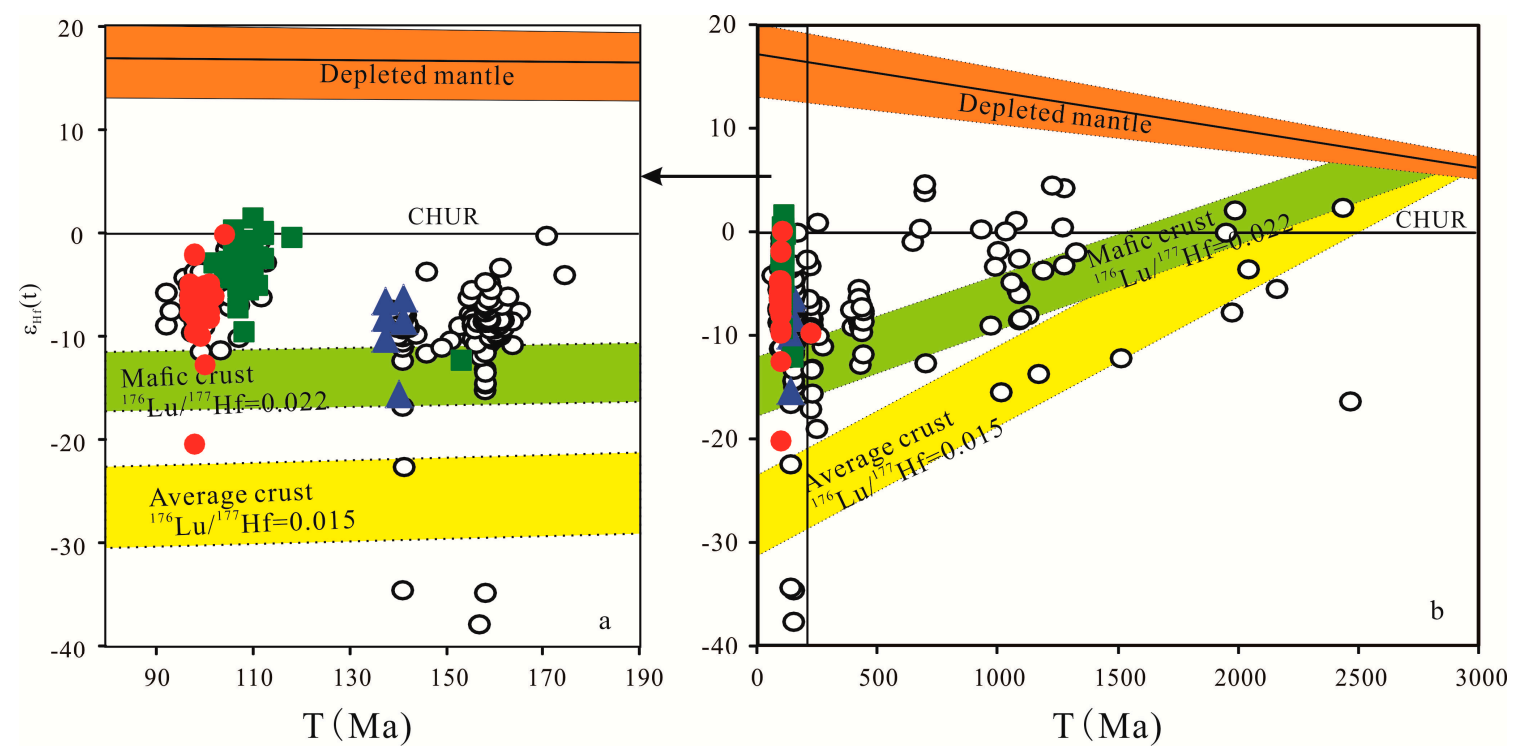

Figure 7. Plot of zircon $\varepsilon \mathrm{Hf}(\mathrm{t})$ values versus $\mathrm{U}-\mathrm{Pb}$ ages for the Magmatic rocks of Zijinshan area. (a) Hf isotopic characteristics of Zircons from the Jurassic to Cretaceous period; (b) Hf zircons from proterozoic to Cretaceous. the ranges for DM, crust, and LC from reference [42].

\section{Discussion}

\subsection{Magmatic Source}

Zircon has high closure temperatures for $\mathrm{U}, \mathrm{Pb}, \mathrm{O}$, and $\mathrm{Hf}$; thus, it is less susceptible to mixing the overlying crustal material during magma ascent. Therefore, these isotopic signatures could represent the geochemical characteristics of the original magma.

As discussed before, the ages of the Zijinshan porphyritic rocks were divided into three groups: Group 1: 138.8 Ma; Group 2: 109.2-107.4 Ma; and Group 3: 99.7-98.2 Ma. In Group 1, the zircon $\delta^{18} \mathrm{O}$ values of sample CX-9 ranged from 6.96 to $8.17 \%$ (Figure 6 ), which was higher than the primitive mantle value $(5.3 \pm 0.3 \%$ ) $[19,20]$. Meanwhile, the $\varepsilon \mathrm{Hf}(\mathrm{t})$ values of the Group 1 zircon ranged from -6.1 to -15.3 (Figure 7). The relatively high $\delta^{18} \mathrm{O}$ and low $\varepsilon H f(t)$ values suggest that crustal material played an important part in magma genesis. The fact that the Hf two-episode depleted mantle model ages $\left(\mathrm{T}_{\mathrm{DM} 2}\right)$ of the Group 1 zircons were mainly in the range of 1576-1818 Ma (except one in $2156 \mathrm{Ma}$ ) implies the presence of a late Proterozoic crustal source for the Group 1 porphyritic rocks (Supplementary Table S3; Figure 8).

The $\delta^{18} \mathrm{O}$ values of the Group 2 zircons ranged from $5.54 \%$ to $7.72 \%$, which were closer to the mantle value when compared to the other zircons groups. The $\varepsilon \mathrm{Hf}(\mathrm{t})$ values of the zircons ranged from 1.6 to -5.3 , which belonged to the region between the depleted mantle and mafic crust. The low $\delta^{18} \mathrm{O}$ and high $\varepsilon \mathrm{Hf}(\mathrm{t})$ values reflected a higher proportion of mantle material contributing to the acidic magma. The Group 2 zircons had $\mathrm{Hf}_{\mathrm{DM} 2}$ ages that were mainly in the range of 1066-1535 Ma (except two zircons aged at $1759 \mathrm{Ma}$ ), indicating the presence, among the others, of a Middle Proterozoic crustal source (Figure 8). Magmatic emplacement in this period probably resulted from the upwelling of the asthenosphere. 


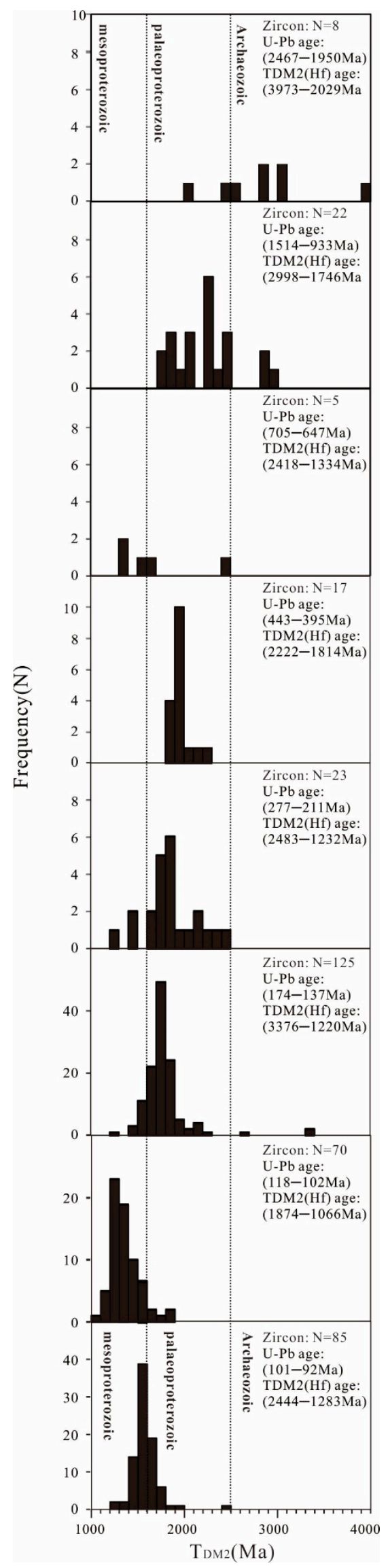

Figure 8. Hf two-stage model age distribution histograms. 
The $\delta^{18} \mathrm{O}$ values of the Group 3 zircons ranged from $6.34 \%$ to $7.62 \%$, with one having an extremely high value $\left(\delta^{18} \mathrm{O}=9.02\right.$ of SF-4@11). The $\varepsilon H f$ values ranged from 0.0 to -7.5 , with two extremely low $\varepsilon \mathrm{Hf}(\mathrm{t})$ values. One zircon grain (SF-4@11) had a calculated $\varepsilon H f(t)$ of -12.5 , associated with a high $\delta^{18} \mathrm{O}$ value $\left(\delta^{18} \mathrm{O}=9.02 \%\right.$ ). Another grain (SMS-1@9) had the lowest $\varepsilon \mathrm{Hf}(\mathrm{t})$ of -20.4 , but with a normal $\delta^{18} \mathrm{O}$ value $\left(\delta^{18} \mathrm{O}=6.34 \%\right.$ ). Most zircons had $\mathrm{Hf}_{\mathrm{DM} 2}$ ages of $1400-1700 \mathrm{Ma}$ (Figure 8 ). Therefore, it is possible that the Group 3 rocks had a mixed source composed of Group 1 and Group 2 rocks. In Group 3, the influence of mantle-derived magma was less than that in Group 2, and there was an increasing tendency indication of the crustal source. The $\delta^{18} \mathrm{O}$ and $\varepsilon \mathrm{Hf}(\mathrm{t})$ values also showed the mixing characteristic of Group 1 and Group 2 magma.

In summary, Group 2 was more affected by mantle-derived magmas. This conclusion is consistent with previous studies arguing that the late Early Cretaceous was an important ore-forming period, and some ore-forming elements were derived directly from the mantle. It has been widely accepted that Cretaceous magmatic rocks formed in an extensional tectonic setting and are probably related to subduction of the Western Pacific plate [4,14].

\subsection{Regional Magmatic Evolution}

Combined with the previous data of the SIMS U-Pb age of magmatic zircons, it can be summarized that the magmatic activities in the southwestern Fujian Province can be divided into eight main periods. The zircon $\mathrm{O}$ and $\mathrm{Hf}$ data indicated that the different episodes of magmatic rocks had different $\delta^{18} \mathrm{O}$ and $\varepsilon H f(t)$ signatures, reflecting different magma sources and tectonic environments $[43,44]$. Following is a summary of the magmatic zircons categorized by period. Some of them were captured by granite and mafic dikes, some samples were directly crystallized from intermediate-acid magmatic rocks, and the rest were sampled from the metamorphose basement of Precambrian.

\section{Paleoproterozoic (2467 1950 Ma)}

Zircons of Early Proterozoic ages were collected from basaltic dikes [41]. The measured $\delta^{18} \mathrm{O}$ values $\left(4.42-8.09 \%\right.$; average $5.81 \%$ ) of these zircons were close to the $\delta^{18} \mathrm{O}$ value of the zircons crystallized from mantle-derived magmas [19]. The $\varepsilon \mathrm{Hf}(\mathrm{t})$ values of these zircons were mainly between 2.2 and -7.9 , falling within the depleted mantle and average crust. The Hf two-stage depleted mantle model ages ( $\mathrm{T}_{\mathrm{DM} 2}$ ) were mainly in the Archaeozoic (Figure 8 ). This indicated that the magmatism was derived from the partial melting of an ancient depleted mantle and an Archaeozoic crust.

\section{Mesoproterozoic (1514 933 Ma)}

The Mesoproterozoic magmatic zircons from our study displayed a large variation both in Hf isotopic compositions $(\varepsilon \mathrm{Hf}(\mathrm{t})=$ from 4.5 to -15.5$)$ and in oxygen isotopic compositions ranging from a lower than the normal mantle value of $3.79 \%$ to supracrustal component of $9.14 \%$. Most of the Mesoproterozoic zircons yielded Paleoproterozoic $\mathrm{T}_{\mathrm{DM} 2}$ ages $(1.7-2.5 \mathrm{Ga})$. These characteristics implied that the Mesoproterozoic magmatism was generated mainly by the partial melting of the Paleoproterozoic crustal materials and mixed with depleted mantle-derived magmas.

\section{Middle Neoproterozoic (705 647 Ma)}

Only five captured magmatic zircon grains were dated during this period. Their values of $\delta^{18} \mathrm{O}$ and $\varepsilon H f(t)$ varied in a limited range. This suggests that, from the Late Proterozoic to Pre-Silurian, there was probably no significant magmatism in this area.

4. Silurian to Lower Devonian (443 395 Ma)

Zircons analyzed from this period showed relatively low $\varepsilon \mathrm{Hf}(\mathrm{t})$ values and plotted along the mafic crustal evolution line (Figure 8). The $\delta^{18} \mathrm{O}$ values of the zircons were higher than those of the others (Figure 7). The calculated $\mathrm{Hf} \mathrm{T}_{\mathrm{DM} 2}$ ages were within the Paleoproterozoic (Figure 8). This suggested that magma mainly came from the partial melting of the Paleoproterozoic mafic crust and mantle materials had a smaller contribution. 


\section{Permian to Triassic (277 211 Ma)}

In this period, the $\varepsilon \mathrm{Hf}(\mathrm{t})$ and $\delta^{18} \mathrm{O}$ values of zircons varied over a wide range. This suggested magmatic mixing between the depleted mantle and mafic crust. However, the contribution of mantle material to magma was more significant than that of the previous Silurian magmas. The age of the crustal source was mainly Paleoproterozoic, with a minor contribution from the Middle Proterozoic crust.

6. Middle Jurassic to Early Lower Cretaceous (174 137 Ma)

Late Jurassic granites were found to be widely distributed in the Zijinshan area. The magmatic zircons generally showed $\varepsilon \mathrm{Hf}(\mathrm{t})$ values of $<0$ and $\delta^{18} \mathrm{O}$ values of $>6$. Zircon $\mathrm{Hf} \mathrm{T}_{\mathrm{DM} 2}$ ages were mainly from the Paleoproterozoic. This was the result of mixing of the mantle source material and the molten magma of the Paleoproterozoic crust.

\section{Late Lower Cretaceous (118 102 Ma)}

Cretaceous shallow intrusive and volcanic rocks were found to be widely distributed in the Zijinshan area, with limited variations in $\varepsilon \mathrm{Hf}(\mathrm{t})$ and $\delta^{18} \mathrm{O}$ values. This indicated that the composition of the source region was relatively homogeneous. The low $\delta^{18} \mathrm{O}$ and high $\varepsilon \mathrm{Hf}(\mathrm{t})$ values suggested that the strongest mantle-derived magma intrusion occurred in this area in the Paleozoic. For all the magmatic activity in the region, only zircons from this period showed that the crustal component of the magma source was from the partial melting of the Middle Proterozoic strata, as shown by their $\mathrm{Hf}_{\mathrm{DM} 2}$ ages (Figure 8). This period was an important $\mathrm{Cu}-\mathrm{Au}-\mathrm{Ag}$ mineralization period in the Zijinshan region. Both mantle-derived materials and materials derived from the Middle Proterozoic crust probably contributed to large-scale mineralization.

\section{Late Lower Cretaceous to Early Upper Cretaceous (101 92 Ma)}

The compositional ranges of $\varepsilon \mathrm{Hf}(\mathrm{t})$ and $\delta^{18} \mathrm{O}$ values were also relatively limited similar to those observed in the late Early Cretaceous zircons. The limited variation of zircon $\varepsilon \mathrm{Hf}(\mathrm{t})$ and $\delta^{18} \mathrm{O}$ values in the Cretaceous felsic magmatism implied that the lower crust had been transformed into a more uniform lower crust. The zircon $\mathrm{Hf}_{\mathrm{DM} 2}$ in this period, as well as $\varepsilon \mathrm{Hf}(\mathrm{t})$ and $\delta^{18} \mathrm{O}$ values, fell into the range between the Late Jurassic and Earliest Late Cretaceous.

In summary, the Paleoproterozoic crust was the main magmatic source for Mesoproterozoic to Jurassic magmatism (Figure 8). For pre-Mesoproterozoic magmatism (in period 1), crustal materials came from the partial melting of both the Archaeozoic and Paleoproterozoic crusts. Mantle-derived magmas played an important role in the formation of the Mesoproterozoic and earlier magmatism. From Mesoproterozoic to lower Devonian, the role of crustal melting in magmatic genesis gradually increased at the expense of the mantle component (Figures 7 and 8). However, the contribution of mantle-derived materials increased in the magmatism from the Middle Jurassic to the late Lower Cretaceous (from period 6 to period 7). Intensive crust-mantle interactions may have caused a higher degree of the partial melting of the Mesoproterozoic crust. Mantle and Mesoproterozoic crustal materials provided sufficient ore-forming components and eventually led to the formation of large-scale deposits in the region. Period 8 was a continuation of Late Early Cretaceous magmatism. At this time, the mantle source invasion was reduced, the crust source became more homogeneous, and some mineralization continued.

\section{Conclusions}

(1) The ages of Mesozoic porphyritic rocks in the Zijinshan ore field region could be divided into three groups: Group 1: 138.8 Ma; Group 2: 109.2-107.4 Ma; and Group 3: 99.7-98.2 Ma. Mantle-derived magma made a significant contribution to the Group 2 porphyries.

(2) Based on all the available SIMS U-Pb age data of the zircons, the medium-acidic magmatism in the southwestern Fujian province could be divided into eight periods: Paleoproterozoic, Mesoproterozoic, 
Middle Neoproterozoic, Silurian to Lower Devonian, Permian to Triassic, Middle Jurassic to Early Lower Cretaceous, Late Lower Cretaceous, and Late Lower Cretaceous to Early Upper Cretaceous.

(3) Paleoproterozoic crust was the main magmatic source for Mesoproterozoic to Jurassic magmatism, but only magmatism that was closely related to mineralization was derived from partial melting of the Mesoproterozoic crust and a more depleted mantle.

(4) Intensive crust-mantle interactions may have caused a higher degree of partial melting of the Mesoproterozoic crust. Mantle and Mesoproterozoic crustal materials provided sufficient ore-forming components and eventually led to the formation of large-scale deposits in the region.

Supplementary Materials: The following are available online at http://www.mdpi.com/2075-163X/10/12/1143/s1, Supplementary Table S1: U-Pb zircon dating results of the porphyritic rocks from the Zijinshan area; Table S2: Whole-rock geochemical data of the porphyritic rocks from the Zijinshan area; and Table S3: Hafnium and oxygen isotopes of the porphyritic rocks from the Zijinshan area.

Author Contributions: Conceptualization, W.Z. and L.W.; investigation, X.L. (Xiaomin Li); data curation, S.Y., J.N. and X.L. (Xupeng Lv); writing—original draft preparation; W.Z.; writing—review and editing; L.W. All authors have read and agreed to the published version of the manuscript.

Funding: This research was funded by National Natural Science Foundation of China, grant number $41873012,41903007$.

Acknowledgments: We would like to thank Yue-Heng Yang for help in zircon analysis, Qiu-Li Li and other colleagues from IGGCAS for help in SIMS O analysis.

Conflicts of Interest: The authors declare no conflict of interest.

\section{References}

1. Zhang, J.Z. Geology, exploration model and practice of Zijinshan ore concentrated area. Miner. Depos. 2013, 32, 757-766.

2. Zhong, J.; Chen, Y.J.; Pirajno, F. Geology, geochemistry and tectonic settings of the molybdenum deposits in South China: A review. Ore Geol. Rev. 2017, 81, 829-855.

3. Sillitoe, R.H. Porphyry copper systems. Econ. Geol. 2010, 105, 3-41.

4. Jiang, S.H.; Liang, Q.L.; Bagas, L.; Wang, S.H.; Nie, F.J.; Liu, Y.F. Geodynamic setting of the Zijinshan porphyry-epithermal $\mathrm{Cu}-\mathrm{Au}-\mathrm{Mo}-\mathrm{Ag}$ ore system, SW Fujian Province, China: Constraints from the geochronology and geochemistry of the igneous rocks. Ore Geol. Rev. 2013, 53, 287-305.

5. Zhao, X.Y.; Zhong, H.; Mao, W.; Bai, Z.J.; Xue, K. Molybdenite Re-Os dating and la-icp-ms trace element study of sulfide minerals from the zijinshan high-sulfidation epithermal cu-au deposit, Fujian province, China. Ore Geol. Rev. 2020, 118, 103363.

6. Zhong, J.; Chen, Y.J.; Pirajno, F.; Chen, J.; Li, J.; Qi, J.P.; Li, N. Geology, geochronology, fluid inclusion and $\mathrm{H}-\mathrm{O}$ isotope geochemistry of the Luoboling porphyry Cu-Mo deposit, Zijinshan orefield, Fujian Province, China. Ore Geol. Rev. 2014, 57, 61-77.

7. Zhang, D.Q.; She, H.Q.; Li, D.X.; Feng, C.Y. The porphyry-epithermal metallogenic system in the Zijinshan. Acta Geol. Sin. 2003, 77, 253-261.

8. Chen, J.; Chen, Y.J.; Zhong, J.; Sun, Y.; Li, J.; Qi, J.P. Fluid inclusion study of the Wuziqilong Cu deposit in the Zijinshan ore field, Fujian Province. Acta Petrol. Sin. 2011, 27, 1425-1438.

9. Chen, J.; Chen, Y.J.; Zhong, J.; Sun, Y.; Qi, J.P.; Li, J. Geological and ore-fluid characteristics of Longjiangting Cu deposit in Zijinshan orefield, Fujian Province, and their genetic implications. Miner. Depos. 2015, 34, 98-118.

10. Jiang, S.H.; Bagas, L.; Liang, Q.L. New insights into the petrogenesis of volcanic rocks in the Shanghang Basin in the Fujian Province, China. J. Asian Earth Sci. 2015, 105, 48-67.

11. Li, B.; Jiang, S.Y. Geochronology and geochemistry of Cretaceous Nanshanping alkaline rocks from the Zijinshan district in Fujian Province, South China: Implications for crust-mantle interaction and lithospheric extension. J. Asian Earth Sci. 2014, 93, 253-274. 
12. Pan, J.Y.; Ni, P.; Chi, Z.; Wang, W.B.; Zeng, W.C.; Xue, K. Alunite 40Ar/39Ar and Zircon U-Pb constraints on the magmatic-hydrothermal history of the Zijinshan highsulfidation epithermal $\mathrm{Cu}$-Au deposit and the adjacent luoboling porphyry $\mathrm{Cu}-\mathrm{Mo}$ deposit, South China: Implications for their genetic association. Econ. Geol. 2019, 114, 667-695.

13. Huang, W.T.; Liang, H.Y.; Wu, L.; Wu, J.; Li, J.; Bao, Z.W. Asynchronous formation of the adjacent epithermal Au-Cu and porphyry Cu-Mo deposits in the Zijinshan orefield, southeast China. Ore Geol. Rev. 2018, 102, 351-367.

14. Li, B.; Jiang, S.Y. A subduction-related metasomatically enriched mantle origin for the Luoboling and Zhongliao Cretaceous granitoids from South China: Implications for magma evolution and $\mathrm{Cu}-\mathrm{Mo}$ mineralization. Int. Geol. Rev. 2015, 57, 1239-1266.

15. Li, B.; Jiang, S.Y. Genesis of the giant Zijinshan epithermal Cu-Au and Luoboling porphyry Cu-Mo deposits in the Zijinshan ore district, Fujian Province, SE China: A multi-isotope and trace element investigation. Ore Geol. Rev. 2017, 88, 753-767.

16. Li, B.; Zhao, K.D.; Yang, S.Y.; Dai, B.Z. Petrogenesis of the porphyrictic dacite from Ermiaogou Cu-Au deposit in Zijinshan orefield and its metallogenetic implications. Acta Petrol. Sin. 2013, 29, 4167-4185.

17. Piquer, J.; Cooke, D.R.; Chen, J.; Zhang, L. Synextensional emplacement of porphyry Cu-Mo and epithermal mineralization: The Zijinshan district, southeastern China. Econ. Geol. 2017, 112, 1055-1074.

18. Li, X.H.; Liu, Y.; Li, Q.L.; Guo, C.H. Precise determination of Phanerozoic zircon $\mathrm{Pb} / \mathrm{Pb}$ age by multicollector SIMS without external standardization. Geochem. Geophys. Geosyst. 2009, 10, 1-21.

19. Valley, J.W. Oxygen isotopes in zircon. Rev. Mineral. Geochem. 2003, 53, 343-385.

20. Cavosie, A.J.; Kita, N.T.; Valley, J.W. Primitive oxygen isotope ratio recorded in magmatic zircon from the Mid-Atlantic Ridge. Am. Miner. 2009, 94, 926-934.

21. Eiler, J.M. Oxygen isotope variations of basaltic lavas and upper mantle rocks. Rev. Mineral. Geochem. 2001, 43, 319-364. [CrossRef]

22. Bindeman, I.N.; Eiler, J.M.; Yogodzinski, G.M.; Tatsumi, Y.; Stern, C.R.; Grove, T.L.; Portnyagin, M.; Hoernle, K.; Danyushevsky, L.V. Oxygen isotope evidence for slab melting in modern and ancient subduction zones. Earth Planet. Sci. Lett. 2005, 235, 480-496. [CrossRef]

23. Bindeman, I.N.; Serebryakov, N.S. Geology, petrology and $\mathrm{O}$ and H isotope geochemistry of remarkably O-18 depleted Paleoproterozoic rocks of the Belomorian Belt, Karelia, Russia, attributed to global glaciation 2.4 Ga. Earth Planet. Sci. Lett. 2011, 306, 163-174. [CrossRef]

24. Searle, M.P.; Miller, J.A.; Rollinson, H.; Jeon, H.; Cavosie, A.J.; Raub, T.D.; Evans, N.J.; McDonald, B.J.; Spencer, C.J. Evidence for melting mud in Earth's mantle from extreme oxygen isotope signatures in zircon. Geology 2017, 45, 975-978.

25. Mao, J.W.; Cheng, Y.B.; Chen, M.H.; Pirajno, F. Major types and time-space distribution of Mesozoic ore deposits in South China and their geodynamic settings. Miner. Depos. 2013, 48, 267-294.

26. Li, Z.; Qiu, J.S.; Yang, X.M. A review of the geochronology and geochemistry of Late Yanshanian (Cretaceous) plutons along the Fujian coastal area of southeastern China: Implications for magma evolution related to slab break-off and rollback in the Cretaceous. Earth Sci. Rev. 2014, 128, 232-248. [CrossRef]

27. Zhu, R.X.; Xu, Y.G.; Zhu, G.; Zhang, H.F.; Xia, Q.K.; Zheng, T.Y. Destruction of the North China craton. Sci. China Earth Sci. 2012, 55, 1565-1587. [CrossRef]

28. Wang, F.Y.; Ling, M.X.; Ding, X.; Hu, Y.H.; Zhou, J.B.; Yang, X.Y.; Liang, H.Y.; Fan, W.M.; Sun, W. Mesozoic large magmatic events and mineralization in SE China: Oblique subduction of the Pacific plate. Int. Geol. Rev. 2011, 53, 704-726. [CrossRef]

29. So, C.S.; Zhang, D.; Yun, S.T.; Li, D. Alteration-mineralization zoning and fluid inclusions of the high sulfidation epithermal Cu-Au mineralization at Zijinshan, Fujian Province, China. Econ. Geol. 1998, 93, 961-980. [CrossRef]

30. Hattori, K.H.; Keith, J.D. Contribution of mafic melt to porphyry copper mineralization: Evidence from Mount Pinatubo, Philippines, and Bingham Canyon, Utah, USA. Miner. Depos. 2001, 36, 799-806. [CrossRef]

31. Yilmaz, H.; Oyman, T.; Sonmez, F.N.; Arehart, G.B.; Billor, Z. Intermediate sulfidation epithermal gold-base metal deposits in Tertiary subaerial volcanic rocks, Sahinli/Tespih Dere (Lapseki/Western Turkey). Ore Geol. Rev. 2010, 37, 236-258. [CrossRef]

32. Chiaradia, M.; Ulianov, A.; Kouzmanov, K.; Beate, B. Why large porphyry Cu deposits like high Sr/Y magmas? Sci. Rep. 2012, 2, 685. [CrossRef] 
33. Wu, L.Y.; Hu, R.Z.; Li, X.F.; Stuart, F.M.; Jiang, G.H.; Qi, Y.Q.; Zhu, J.J. Mantle volatiles and heat contributions in high sulfidation epithermal deposit from the zijinshan $\mathrm{Cu}-\mathrm{Au}-\mathrm{Mo}-\mathrm{Ag}$ orefield, Fujian province, China: Evidence from he and ar isotopes. Chem. Geol. 2018, 480, 58-65. [CrossRef]

34. Li, Q.L.; Li, X.H.; Liu, Y. Precise U-Pb and Pb-Pb dating of Phanerozoic baddeleyite by SIMS with oxygen flooding technique. J. Anal. At. Spectrom. 2010, 25, 1107-1113. [CrossRef]

35. Wiedenbeck, M. Three natural zircon standards for U-Th- $\mathrm{Pb}$, Lu-Hf, trace element and REE analyses. Geostand. Geoanal. Res. 1995, 19, 1-23. [CrossRef]

36. Ludwig, K.R. User's Manual for Isoplot 3.00; Berkeley Geochronology Center: Berkeley, CA, USA, 2003; 70p.

37. Li, X.H.; Li, Z.X.; He, B.; Li, W.X.; Li, Q.L.; Gao, Y. The Early Permian active continental margin and crustal growth of the Cathaysia Block: In situ U-Pb, Lu-Hf and O isotope analyses of detrital zircons. Chem. Geol. 2012, 328, 195-207. [CrossRef]

38. Wu, F.Y.; Yang, Y.H.; Xie, L.W.; Yang, J.H.; Xu, P. Hf isotopic compositions of the standard zircons and baddeleyites used in U-Pb geochronology. Chem. Geol. 2006, 234, 105-126. [CrossRef]

39. Chu, N.C.; Taylor, R.N.; Chavagnac, V.; Nesbitt, R.W.; Boella, R.M.; Milton, J.A.; German, C.R.; Bayon, G.; Burton, K. Hf isotope ratio analysis using multi-collector inductively coupled plasma mass spectrometry: An evaluation of isobaric interference corrections. J. Anal. At. Spectrom. 2002, 17, 1567-1574. [CrossRef]

40. Li, X.H.; Tang, G.Q.; Gong, B.; Yang, Y.H.; Hou, K.J.; Hu, Z.C.; Li, Q.L.; Liu, Y.; Li, W.X. Qinghu zircon: A working reference for microbeam analysis of $\mathrm{U}-\mathrm{Pb}$ age and $\mathrm{Hf}$ and $\mathrm{O}$ isotopes. Chin. Sci. Bull. 2013, 58, 1954-1961. [CrossRef]

41. Belousova, E.A.; Griffin, W.L.; O’Reilly, S.Y.; Fisher, N.I. Igneous zircon trace element composition as an indicator of source rock type. Contrib. Mineral. Petrol. 2002, 143, 602-622. [CrossRef]

42. Griffin, W.L.; Graham, S.; O’Reilly, S.Y.; Pearson, N.J. Lithosphere evolution beneath the Kaapvaal Craton: Re-Os systematics of sulfides in mantle-derived peridotites. Chem. Geol. 2004, 208, 89-118. [CrossRef]

43. Zhang, W.H.; Wang, C.Z.; Li, X.M.; Liu, W.Y. Zircon SIMS U-Pb age, Hf and O isotopes of mafic dikes, southwest Fujian Province. Adv. Earth. Sci. 2016, 31, 320-334.

44. Zhang, W.H.; Wang, C.Z.; Li, X.M.; Liu, W.Y. A primary discussion on magmatic evolution series in the Zijinshan area, Fujian Province: Evidences from zircon SIMS U-Pb ages and Hf, O isotopes. Bull. Min. Petrol. Geochem. 2017, 36, 98-111.

Publisher's Note: MDPI stays neutral with regard to jurisdictional claims in published maps and institutional affiliations.

(C) 2020 by the authors. Licensee MDPI, Basel, Switzerland. This article is an open access article distributed under the terms and conditions of the Creative Commons Attribution (CC BY) license (http://creativecommons.org/licenses/by/4.0/). 